\title{
Computerised Experiments in the Web Environment
}

\author{
Martin BULLA, Stanislav HOLEC \\ Department of Physics, Faculty of Natural Sciences, Matej Bel University \\ Tajovského 40, 97401 Banská Bystrica, Slovakia \\ e-mail: bulla@fpv.umb.sk,holec@fpv.umb.sk
}

Received: August 2004

\begin{abstract}
This paper presents various methods of computer aided experiments in science education and their integration in Web environment as HTML documents. The concept of the virtual laboratory suitable for science teaching at the secondary school level is described. Some essentials and advantages of this approach are presented in the paper. They are illustrated with a concrete example of the course Integrated Science through Experiments that has been developed as a product of the European funded project Computerised Laboratory in Science and Technology Teaching within the Leonardo da Vinci II programme. The paper outlines the structure of the course accessible to the user via a tabular system of links.
\end{abstract}

Key words: computerised and web-based laboratories, science education, computer aided experiments, integrated science.

\section{Introduction}

Computer equipment (hardware, software, devices for searching and transport of information) is an absolutely indispensable part of the scientific research nowadays. Transformation of scientific research methods using computer equipment into the teaching process is one of the imperatives for theories of science education. This has especially a great meaning in experimental activities. An experiment is often used as a starting point for an introduction of new information and concepts in the teaching and learning process.

Computer aided experiments have become an important part of modern teaching strategies. According to a performance and application methods we can find following classification of computer aided experiments: real experiments, simulations and quantitative model experiments (Holec, 1999). Performing the real experiments in the classroom is an optimal way in order to make teaching and learning process effective. But model experiments are very suitable complements of the real experiments. They can help to find the corresponding relations, dependencies and contents of the phenomena.

Some factors and reasons do not enable performing the real experiments at schools in some cases. The necessary equipment and conditions are not available sometimes or it is impossible to perform the real experiments because of the safety regulations. Therefore it seems to be useful and suitable to integrate different computerised experimental methods 
into a comprehensive environment and provide the experiments for teachers and students in electronic form. An appropriate platform that enables this integration is HTML document.

Many advantages of this approach have already appeared in connection with the course Integrated Science through Experiments. It has been developed by Department of Physics of Matej Bel University in Banska Bystrica as the product of the European funded project Computerised Laboratory in Science and Technology Teaching within the Leonardo da Vinci II programme. It is a hands-on and HTML-based course that includes an integration of various methods of the computer aided experiments. In this paper we focus on the essentials and benefits of this conceptual framework of the virtual laboratory and the structure of the course Integrated Science through Experiments.

\section{Computer Aided Experiments}

\subsection{Real Computer Aided Experiments}

There are three basic components for performing of real computer aided experiments: a sensor, an interface and a computer connected with each other. It is an advantage if the interface has own data medium to save acquired data from several measurements. Possibility to connect more sensors and to use them at the same time should be obvious. The experimental set up can be complemented with other devices e.g. a printer. This equipment is used:

- to control the measurement of quantities according to entered criteria;

- to save acquired data into the selected data medium for later processing or to process them immediately;

- to display data as a graph or a table with different modifications that depend on the used software;

- to provide data in a printed form;

- to enable transmission of acquired data for processing by other tools (text editor, spreadsheet).

The software for the control of the measurement has to enable processing of measured data (tables, graphs, other functions).

\subsection{Computer Simulations}

The method of simulated model experiments consists of development and application of the models that represent real phenomena in the nature. Behaviours of these phenomena are simulated using suitable software applications. Such tools as Java applets, GIF animations and software for modelling (Interactive Physics, Modelus) are used for their creation. They enable to investigate and discover relationships and manipulate with variables (Raganová and Murin, 1998).

The use of this method in the classroom has several advantages. First of all the abilities of students to test hypothesis are evolved. A support of science teaching in the area of 
abstract topics is also one of the special benefits of this method. An attractive performance of simulations, their high resolution level, a possibility to use colours, a deceleration or acceleration of actions are factors that make learning more effective. Dynamically represented phenomena are more interesting and attractive and so the method has strong motivational effects (Raganová, 1999).

\subsection{Quantitative Model Experiments}

This is the method of the creation and working with mathematical models that can be set up on the spreadsheets (Excel, Lotus). It is relatively a new type of model experiments that provide results of required calculations (often complicated, repeated and long) during a short time. It enables to display results as a graph, too. It is possible to make use of these features of quantitative model experiments:

- creating of tables with acquired data;

- sorting of data and drawing the graphs;

- displaying functionality between variables;

- development of tables with mathematical formulas;

- supplying the long counts;

- verification of created mathematical models during a short time;

- simple and fast possibilities to change conditions and settings of the experiment;

- development of applications for own research activities.

\section{Items Available in the Virtual Laboratory}

An appropriate environment that enables the integration of various methods of computer aided experiments is HTML document. A virtual laboratory accessible for long distances via the Internet arises by this way. Schemes, photographs, videos of the real experiments together with data acquired during the real experiment (as a table and a graph) can be simply complemented with computer simulations of phenomena and quantitative mathematical models. The structure of the experiment description should be designed so that all items of this description are accessible to the user via tabular system of links. Variants of the experiments, suggestions for additional activities, a theoretical background, and relations to life, nature and practice may be a part of the experiment structure, too.

All of this enables the interactive activities for students because a wide spectrum of items and materials including acquired data is available for them. Students can use a spreadsheet to set up mathematical models of the phenomenon or can enter results from the real experiment into a spreadsheet to extrapolate or work out the course of the functionality or some measured quantities. It is advisable if there are simulations of real phenomena in the virtual laboratory. Students can change initial conditions and compare results with acquired data during the real experiment or a mathematical model set up on the spreadsheet. There are two ways how to use the products and items in the virtual laboratory. They can serve either as a resource of the themes and instructions for performing the real experiments or for the presentation of the real experiments through the virtual laboratory. 


\section{The Course Integrated Science through Experiments}

The course material begins with information of textbooks and Web sources appropriate as an additional reading to enable deeper understanding of phenomena and processes presented in experimental activities. The opening page is followed with a list of experiments that are divided into groups according to their curriculum contents.

The most of the material is designed to be understandable for secondary school students. This strategy enables to introduce the course for all of the future physics, biology and chemistry teachers, who as a consequence of separated teaching of sciences and the relevant way of teacher training usually have deep knowledge only from one of the science branches. Some of the suggested activities use phenomena or need an analysis appropriate for university students. Html form of the course allows the teacher an easy selection of the experiments that are suitable for the particular group of students (Holec et al., 2003).

\subsection{Student's Guide}

The Student's guide is designed as a set of instructions that led the student to perform the offered experimental activity. The structure of the Student's guide consists of:

- a motivating problem with a brief theoretical background;

- a list of needed aids;

- a scheme of the experiment presented as a drawn picture or a photograph of the apparatus;

- a set of instructions for the apparatus setting up supplemented with a video record;

- a set of tasks to help the student to analyse and to interpret the gained data;

- questions that lead students to summarise the experimental results and to find expected relationship between variables or to solve the given problem;

- links of the investigated phenomena to the life, the nature and the practice;

- suggestions for further exploration, links to other relevant experiments and additional tasks that aim to encourage students' motivation and creativity.

\subsection{Teacher's Guide}

The Teacher's guide contains needed information concerning the integration of offered experimental activities into the classroom. Even when the use of IT is generally considered as necessary in science education, a lot of teachers have still felt a bit scared to perform the computer-supported experiments. The detailed course material containing a lot of pictures, photographs and particular instructions and notes should help teachers to overcome their fear.

The Teacher's guide is broadened in some points comparing with the Student's guide. These include concepts regarding to the experiment, purpose of the experiment and background notes with safety warnings. The experimental data are offered to the teacher in the both numerical and graphical forms and serve as a working example that can be used 
in the case when the suggested activity will be performed less or more as a virtual laboratory. This is especially true in the case of experiments with radioactive sources that are difficult to perform at the secondary school classroom. Instructions for data analysis, conclusions from the experiment and suggestions for student activities are also provided.

\section{Conclusion}

The presentation of the real experiments through the virtual laboratory brings new opportunities for science teaching and learning when there are not conditions for their performing at schools or because of the safety regulations. But an interactivity of this approach is an extra value for the learners. The integration of listed items in Web environment as HTML document provides for the users (teachers, students) an accessibility for long distances and many possibilities to take an active part in experiments including opportunities to change experimental conditions. A combination of various methods of computer aided experiments brings advantages of a multiple effect on the recipient. It enables to interiorise and acquire the content of the presented phenomenon effectively. Though, it is necessary to accentuate that all of this does not reduce the value of real experiments in science education that are performed live.

\section{References}

Holec, S. (1999). Posilnenie experimentálnej bázy výučby prírodovedných predmetov (in Slovak, The reinforcement of the experimental base of science teaching). In S. Holec (Ed.), Vybrané problémy z didaktiky prírodovedných predmetov. Fakulta prírodných vied Univerzity Mateja Bela v Banskej Bystrici, Banská Bystrica, pp. 5-36.

Holec, S. et al. (2003). Integration of ICT into learning activities within science education. In E. Mechlová (Ed.), Information and Communication Technology in Education. Př́rodovědecká fakulta Ostravské univerzity, Ostrava, pp. 89-93.

Raganová, J., and M. Murin (1998). Metóda modelových experimentov vo vyučovaní fyziky (in Slovak, The method of model experiments in physics teaching). In J. Krajčo and J. Klima (Eds.), Acta Universitatis Matthiae Belii - FPV II/98 Fyzika. Fakulta prírodných vied Univerzity Mateja Bela v Banskej Bystrici, Banská Bystrica, pp. 117-123.

Raganová, J. (1999). Počítačové modely vo vyučovaní prírodovedných predmetov na základných školách (in Slovak, Computer models in science teaching in primary schools). In S. Holec (Ed.), Vybrané problémy z didaktiky prírodovedných predmetov. Fakulta prírodných vied Univerzity Mateja Bela v Banskej Bystrici, Banská Bystrica, pp. 103-111. 
M. Bulla is currently a senior lecturer at the Department of Physics, Faculty of Natural Sciences, Matej Bel University in Banska Bystrica, Slovakia. His research interests include theory of science teaching, information and communication technologies in education, web-based education, computer aided experiments, virtual laboratories and nonformal education.

S. Holec is a dean of Faculty of Natural Sciences, Matej Bel University in Banska Bystrica, Slovakia. He has more than 15 years of experience teaching physics at future physics teachers training programme, where he has specialized at optics. He has published widely; his research work concentrates on didactics of physics and science, especially on real and model physics and science school experiments aided by the computer. He was involved in several curriculum and resource development projects. He coordinated the Joint European Project Tempus (1995-1998) focused on science teacher training.

The authors took an active part in the European funded project Computerised Laboratory in Science and Technology Teaching within the Leonardo da Vinci II programme (2000-2004). They have presented their work at many national and international conferences.

\section{Kompiuteriniai eksperimentai žiniatinklio terpèje}

Martin BULLA, Stanislav HOLEC

Straipsnyje supažindinama su ivairiomis kompiuterio taikymo mokymo procese galimybemis. Pateikiama virtualiosios laboratorijos, pritaikytos mokymuisi vidurinèse mokyklose, koncepcija. Aptariami tokio mokymo būdo svarbiausi bruožai bei privalumai. Dėstoma medžiaga remiasi patirtimi, igyta rengiant kursą "Integruoti gamtos mokslai, pagrịsti eksperimentais". Kursas paruoštas igyvendinant Leonardo da Vinci II programos remiama projekta "Kompiuterinès laboratorijos mokant gamtos mokslu ir technologiju". Straipsnyje pateikiami kurso, klausytojui prieinamo naudojantis nuorodų sistema, struktūros metmenys. Aptariami pirminiai šio kurso vertinimo rezultatai. 